Hidayati, I.A., \& T.Taufik (2020). Adversity quotient of outstanding students with limited conditions. Indigenous: Jurnal Ilmiah Psikologi, 5(2). 195-206. doi: https://doi.org/10.23917/ indigenous.v5i 2.10823

\title{
Adversity Quotient of Outstanding Students with Limited Conditions
}

\author{
Isnaya Arina Hidayati ${ }^{1}$ Taufik $^{2}$
}

Fakultas Psikologi, Universitas Muhammadiyah Surakarta ${ }^{1,2}$

isnaya.arina@ums.ac.id', taufik@ums.ac.id²

\begin{abstract}
This study aims to explore and explain the dynamics of adversity quotient, the supporting and inhibiting factors of adversity quotient of outstanding students with limited conditions. The informant characteristics of this study are outstanding students with limited condition (students who are needy with the broken home family and experiencing violence from their family) residing in Solo, who attend junior and senior high school and college students. There are 3 informants and 9 informants complementary by purposive sampling method, with in-depth interviews and participative observation method. The data were analyzed by deductive descriptive analysis. The results of this study show that the dynamic of the Informant's adversity quotient to control economic difficulties with frugal behavior and concerned attitudes. Good self-regulation in controlling difficult situations so as not to widen and influence the educational dimension. Resilience behavior is more apparent in the informants of victims of broken homes and survivors of domestic violence. Gratitude makes the informant more eager to rise from adversity to achieve a better life, accompanied by strong motivation and relational efficacy between mother and informant. The supporting factor is derived from internal factors such as competitiveness, coping behavior, and the ability of improvement (resilience), visionary and strong internal motivation, self-awareness, and the ability to think positively with gratitude. While external factors mostly come from the social support of family, other students, and community. The inhibiting factors namely are the problem of emotion-regulation such as less stable emotional state, poverty, dysfunction of family's role, and the problem of fatherless families. It is concluded that a compensation made by the informant with self-regulation, gratitude in increasing resilience and the relational efficacy of family members in strengthening the struggle for achievement. The world of education, both in the family, school, and community circles, can play an active role in shaping the quality of the next generation by equipping the adversity quotient-intelligence from an early age so that they have a strong mentality in facing various life problems in the future.
\end{abstract}

Keywords: adversity quotient; outstanding students; limited conditions

\section{INTRODUCTION}

The success of children in achieving their ideal achievements is influenced by supporting factors that are fulfilled perfectly. These factors include school, educators, home environment, peer groups, and the internal condition of the family. The role of parents is the most important factor in a child's success in gaining the achievement. Fulfilling the needs of love, providing education 
and supporting facilities, are part of the role of parents in contributively helping children's success (Acharya \& Joshi, 2011; Manurung, 2008).

Based on this statement, parental support, both emotionally and economically, will greatly affect the success of children's achievement. But it is different with what happen in several educational institutions where some students who get the predicate of outstanding students have limitations. These limitations include, among others, low income families, children who are domestic violence survivors, victims of broken homes, and those related to the failure of parents to properly supervise and protect children.

According to law No. 11 (2009) and Scott et al. (2014), welfare is a condition for the fulfillment of the material, spiritual, and social needs of citizens in order to live properly with protection, safety and security and to be able to develop themselves so that they can carry out their social functions. Dimensions of human welfare, namely, having knowledge, good social interaction, self-acknowledgment, integrity, health, economic security, freedom, compassion, and wealth.

Referring to PERMENSOS RI no. 8 in the social welfare data and information center (2011) , a person who is not fulfilled or is in the "limited conditions" of several dimensions of welfare mentioned above, can be referred to as a Person with Social Welfare Problems (PMKS). PMKS is a person, family or community group that due to an obstacle, difficulty, or disturbance are unable to carry out their social functions so that their daily needs, both physical, spiritual, and social needs are not sufficient and fair. These obstacles, difficulties or disturbances can be in the form of poverty, disharmony in the family, neglect, disability, social disability, underdevelopment, alienation / underdevelopment, and natural or social disasters.

It can be concluded that the limitation of the conditions here is the deterioration of the situation or the lack of conditions in the family, both in terms of finance so that primary and secondary needs are not fulfilled, as well as from a social perspective which includes the unmet need for affection in the family, such as neglect of children, parental harmony, domestic violence, so that it affects the dimensions of individual welfare.

As an initial basis for research, researchers conducted a pre-liminary study at SMK IT Smart Informatika Surakarta, which was founded by the Solo Peduli foundation. In fact, all the students in this school had poor family backgrounds and experienced several problems with limited conditions. Even so, they could compete with other students and even made achievements. This school was actively participating in championship events both at regional and national levels. Some of the achievements that have just been achieved included runner up in Central Java Mathematics Olympiad, 2nd place in the English Speech Contest at Central Java Vocational High School, 1st and 2nd place in assembling computers in Surakarta. (Preliminary research field notes on 4 February 2016).

It is not easy for individuals who are under pressure in their family environment or with a difficult economic background to survive under these conditions. However, the difficulties they experienced in their environment were not an obstacle to keep working and achieving to elevate their life.

Phoolka \& Kaur (2012) explained how these individuals adapted to the obstacles and problems they faced, so that they were able to turn challenges into opportunities. This concept is called "Adversity Quotient" which was first introduced by Paul. G. Stoltz with the term adversity intelligence, which is the individual's intelligence in facing obstacles or difficulties with persistence and determination while still adhering to the principles and dreams. One of the secrets to overcoming challenges or difficulties for everyone is to increase adversity quotient-intelligence (Stoltz, 2007).

The Ministry of National Education (2007) and the results of research by Markman et al. 
(2002), and Phoolka and Kaur (2012) define adversity quotient as the ability to maintain or achieve something that is done persistently. In the concept of Stoltz (2007), individuals with high adversity quotient, will tend to be responsible for the problems they face when they are in trouble, be able to control problems, are good at finding solutions, and focus on solutions.

There are four dimensions or aspects of adversity quotient which are often abbreviated as CO2RE, namely (C) control, namely how much control the individuals have while faceing the problem; (O2) origin and ownership or origin and recognition, namely what causes the problem and how the consequences are related to oneself; R) reach, which is how a problem affects other dimensions of life, (E) endurance or strength, namely the time response of the problem (Akbar et al., 2014; Chin \& Hung, 2013; Huijuan, 2009; Santos, 2012; Shen, 2014).

According to Stoltz (2007) there are several factors that influence adversity quotient: (a) Competitiveness. adversity quotient is low due to lack of competitiveness when facing difficulties, thus losing the ability to create opportunities in the difficulties faced (Bennu, 2012); (b) Productivity. There is a positive correlation between employee performance or student's achievement with the response given to the difficulties at hand (Ramadhanu \& Suryaningrum, 2014); (c) Strong motivation can create opportunities in adversity (Shen, 2014); (d) Take risks. Research conducted by Sunandar et al. (2018) showed that someone who had high adversity quotient was more willing to take risks from the actions taken. That was because someone with high adversity quotient responded to adversity more constructively; (e) Improvement. A person with high adversity quotient always tries to overcome difficulties with concrete steps (Novianty, 2014), namely by making improvements in various aspects so that these difficulties do not influence other areas; (f) Endurance or persistence. Individuals who respond well to adversity will always survive with the situation and make difficulties a challenge that must be faced; (g) Learning. In facing many obstacles in achieving their goals and dreams, it is hoped that the struggle and persistence in learning will enable them to accomplish good learning achievements.

Azwar (2007) and Maslihah (2011), state that students or students with academic achievement are all the results that have been achieved (achievement) through the academic learning process (academic achievement) which can be used as a measure to determine the extent to which students master the learning material taught and learned. It is different with students who excel not only in academics, but in overall achievement. They are a picture of the ideal students, namely success in academic work and non-academic life; master the field of science that they are engaged in, achieve excellent learning outcomes, can improve skills, develop interests and hone their talents and potential by being active in various extracurricular activities (Direktorat Jendral Pendidikan Tinggi, 2010).

This is a big concern for the researchers in conducting this research that aims to explore and explain how the dynamics of the adversity quotient of students who excel but have limited background conditions as well as supporting and inhibiting factors. So, the research questions formulated are: (1) What are factors that hinder the adversity quotient of outstanding students with limited conditions?; (2) What are factors that support the adversity quotient of outstanding students with limited conditions?; (3) And what is the dynamics of the adversity quotient of outstanding students with limited conditions?

\section{METHOD}

This study used a qualitative method of case study review, involving 2 types of informants, namely primary and secondary. The primary informants were 3 students who were recorded as 
outstanding in school with limited conditions in the form of low income (poor) families, or children who were victims of domestic violence or victims of broken homes or those related to the failure of their parents to properly supervise and protect their children. The secondary informants were companions/parents, teachers, and close friends of the primary informants. The selection of informants was carried out by purposive sampling technique, namely the selection based on the characteristics determined by the researchers.

Data collection was carried out by in-depth interviews. This interview was conducted more than once with one informant. The data collection process according to Creswell (2010) follows a zigzag pattern, where the researchers go to the field looking for information, then analyze the data obtained, return to the field to get more information, analyze data again, and so on.

Hadi (2016) states that valid data can be obtained by testing the validity of the data or testing the credibility of the research data. In this study, the data validity techniques used were source triangulation, extension of observations, and discussion with peers. The extension of the observations in this study was carried out in the data collection process. Here the researchers often visited the school or home to meet the subject, build closeness, sense of comfort and safety. Discussions with peers included providing suggestions, criticism, and direction.

This study used a deductive descriptive data analysis and an open coding stage, with the following steps: (1) Data reduction; (2) Data coding; (3) Connecting the themes set out in the form of a narrative; (4) Data interpretation.

\section{RESULTS AND DISCUSSION}

The researchers mapped the research subjects with their identities, achievements, and problems faced. The first informant with the initials MNS (16 years), the second with the initials AFA (17 years), and the third informant with the initials RRR (19 years).

Table 1.

Problems of outstanding students with limited conditions

\begin{tabular}{|c|c|c|}
\hline Subject & Achievement & Problems \\
\hline $\begin{array}{c}\text { M. N. S } \\
16 \text { years old } \\
\text { SMA N } 1 \text { Sukoharjo }\end{array}$ & $\begin{array}{l}\text { - Ranked I in grade } 1 \text { in junior } \\
\text { high school } \\
\text { - Ranked I in grade } 2 \text { in junior } \\
\text { high school } \\
\text { - Ranked I in grade } 3 \text { in junior } \\
\text { high school } \\
\text { - Ranked in the top } 10 \text { in senior } \\
\text { high school } \\
\text { - 1st place of composing a short } \\
\text { story at the district level } \\
\text { - 2nd place in District level Quiz } \\
\text { competition } \\
\text { - } 2 \text { nd place in the District } \\
\text { Science Olympiad } \\
\text { - 4th place in science clump } \\
\text { competition at UNS }\end{array}$ & $\begin{array}{l}\text { a. Come from a low-income family. His/her father } \\
\text { worked as a ticket salesman at a private automotive } \\
\text { company with irregular income every day. His/her } \\
\text { mother worked as a seller of ice and snacks in a small } \\
\text { shop located in front of our house. The mother's side } \\
\text { income was obtained from her job as a washing worker. } \\
\text { b. The subject continued his/her study with } \\
\text { scholarships from BSM (Poor Student Scholarships) } \\
\text { and At-Taqwa scholarships from an organization in } \\
\text { their area. }\end{array}$ \\
\hline $\begin{array}{c}\text { A.F. A } \\
17 \text { years old } \\
\text { SMA } \quad \text { Al-Abidin } \\
\text { Surakarta }\end{array}$ & $\begin{array}{l}\text { - Ranked I in grade } 1 \text { in junior } \\
\text { high school } \\
\text { - Ranked I in grade } 2 \text { in junior } \\
\text { high school } \\
\text { - Ranked I in grade } 3 \text { in junior } \\
\text { high school }\end{array}$ & $\begin{array}{l}\text { a. Come from a broken home; father and mother } \\
\text { divorced since the subject was in the 5th grade } \\
\text { elementary school. According to the subject's } \\
\text { statement, the cause of divorce was the income } \\
\text { provided by the father was deemed unable to meet the } \\
\text { needs of daily life. In addition, it was also about the } \\
\text { father acts of violence against the mother }\end{array}$ \\
\hline
\end{tabular}




\begin{tabular}{|c|c|c|}
\hline Subject & Achievement & Problems \\
\hline & $\begin{array}{l}\text { - 2nd place in the Biology } \\
\text { Olympiad district level } \\
\text { - 2nd place in the Scout LKTI } \\
\text { competition at the district level }\end{array}$ & $\begin{array}{l}\text { b. The subject felt depressed because the mother } \\
\text { remarried. The second father had a low economic } \\
\text { background. The grandparents paid for school fees } \\
\text { and other necessities. Meanwhile, the father (first) } \\
\text { gave up the responsibility to support the child. }\end{array}$ \\
\hline $\begin{array}{c}\text { R.R.R } \\
19 \text { years old } \\
\text { Universitas Gadjah } \\
\text { Mada }\end{array}$ & $\begin{array}{l}\text { - Ranked } 1 \text { from junior to senior } \\
\text { high schools } \\
\text { - 3rd place in the provincial level } \\
\text { physics Olympiad } \\
\text { - 2nd place in the regency level } \\
\text { in Indonesian and English } \\
\text { competitions } \\
\text { - 3rd place of student with } \\
\text { district level achievement } \\
\text { - 1st place with the highest score } \\
\text { in the National Examination, } \\
\text { from junior to senior high school } \\
\text { levels } \\
\text { - Received outstanding } \\
\text { scholarships from junior high } \\
\text { schools to university }\end{array}$ & $\begin{array}{l}\text { a. His/her father worked as a daily screen-printing } \\
\text { worker with an income of } \pm 100-150 \text { thousand per } \\
\text { day. In the past, the father worked to help neighbors } \\
\text { tidy up books and was valued at } 300-500 \text { rupiah per } \\
\text { kilo. The mother used to work as a factory worker, } \\
\text { domestic helper, laundry employee, until finally she } \\
\text { was able to open a simple laundry service at home. } \\
\text { b. Currently RRR is studying at UGM with scholarship } \\
\text { from Bidikmisi for the achievements made during } \\
\text { junior high school. } \\
\text { c. Father's presence and attention to the subject was } \\
\text { lacking. The father tended to be tough on his/her } \\
\text { mom. }\end{array}$ \\
\hline
\end{tabular}

\section{The factors inhibiting the adversity quotient of outstanding students with limited conditions}

Emotion Regulation. In terms of achievement, an unstable emotional state when facing competitors often made informants discouraged if they got scores that did not match their expectations and were insecure if they saw friends getting higher scores than them. The results of research conducted by Hidayat (2013) showed a significant relationship between self-regulation and learning achievement, where one's success in carrying out the educational process was not only determined by the level of intelligence, but also aspects of metacognition, motivation, and behavior which were part of self-regulation.

Lack of Funds. Finance became an obstacle for informants in completing the learning process. Informants did not buy supporting books and discouraged taking additional lessons or courses, because their parents could not afford them. The inability of families in economic terms affected children's interest and motivation in learning. The difficulty of fulfilling primary needs had led to neglect of secondary needs which were the future needs of the family, in this case the need for education (Dewi et al., 2014).

Fatherless and a crisis of family functioning. According to Lerner (2011) the absence of an important role for the father would have an impact on low self-esteem, feelings of annoyance (anger), and embarrassment (shame). Losing the father's role also caused a child to feel loneliness, envy, grief and loss, which was also accompanied by low self-control, initiative, and courage to take risks ( risk taking), and psychology of well-being, as well as a tendency to have neurotics. The function of the family according to Lubow et al. (2009) refered to how all members of a family could communicate each other, did work together, worked hand in hand in meeting the needs of the family, in this case the need for education (Dewi et al., 2014).

Fatherless and a crisis of family functioning. According to Lerner (2011) the absence of an important role for the father would have an impact on low self-esteem, feelings of annoyance (anger), and embarrassment (shame). Losing the father's role also caused a child to feel loneliness, envy, grief and loss, which was also accompanied by low self-control, initiative, and courage to 
take risks ( risk taking), and psychology of well-being, as well as a tendency to have neurotics. The function of the family according to Lubow et al. (2009) refered to how all members of a family could communicate each other, did work together, worked hand in hand in meeting the needs of their members, where this had an impact on physical and emotional health between the family members. The functioning of the family could increase self-regulation. The results of a partial correlation analysis in a study indicated that family functioning had a significant relationship with self-regulated learning (Herawaty \& Wulan, 2013).

Independence. The fighting ability in general is related to the parenting style that is applied. Parents who already provided a lot of facilities or conveniences tended to reduce the independence and maturity of children in acting and facing problems (Bennu, 2012). Research conducted by Sunarty (2016) showed that barriers to the development of independence in individuals were caused by dependence on parents, permissive parenting, lack of attention or guidance from parents to master developmental tasks related to independence, and lack of motivation to be independent.

\section{Factors supporting the adversity quotient of outstanding students with limited conditions}

Based on the case analysis of the MNS, AFA and RRR informants, it was found that there were factors that supported the informants in achieving their successes despite the limited conditions they experienced. Internal drive, The limited conditions motivated the informants to have higher education and achievement. Motivation and strong belief kept the informants in the face of adversity. Motivation is the psychic driving force in students that causes learning activities, ensure the continuity of learning to achieve one goal. Apart from that, motivation is also very important in providing passion, enthusiasm, and pleasure in learning. Strong motivation is able to create opportunities in adversity, meaning that someone with strong motivation will try to solve difficulties by using their abilities and it is more effective in the process of achieving their success (Shen, 2014; Stoltz, 2007; Wardani \& Saidiyah, 2016).

Informants had strategies to improve their learning achievement, namely observing and imitating the learning styles of smart friends as their role models in accomplishing achievement. Competitiveness (competitor spirit) is one of the factors affecting individual adversity quotient. The existence of individual competitiveness can create opportunities in dealing with problems (Bennu, 2012; Stoltz, 2007).

Self-awareness of the importance of the future, remembering the mother's advice to keep thinking positively, accepting and being grateful for what they were facing were a special spirit for informants to stay strong in facing the problems they were experiencing. In accordance with the opinion of Stoltz (2007) mentioning that resilience and persistence are one of the factors that affect adversity quotient. Individuals who always survive in difficult circumstances will make this situation a challenge that must be faced.

Social Support; a) Family environment, namely factors of family functioning, material and emotional support from parents, appreciation (reward) for achievement. According to (Zainuddin, 2011), how parents educate, parenting styles in the family, affects individual adversity quotient. Emotional support or appreciation can protect a person from negative emotions with consequent stress (Annisa \& Swastiningsih, 2015).

This is in line with the research conducted by Xu et al. (2010) which stated that family warmth and functioning had a relationship with learning based on self-regulation and increasing achievement in children. b) School environment leads to moral and emotional support given from friends and teachers, such as attention, motivation, giving direction and helping to alleviate difficulties. Schools are not only places to seek knowledge, but schools are also able to provide input 
in shaping children's character. At school, children find various kinds of things that can affect them (Zainuddin, 2011).

Community environment, such as scholarship assistance, awards or coaching money from institutions or groups of community organizations. Learning support facilities are also given from neighbors or relatives. The community environment can be in the form of neighbors, people who are considered close around individuals, or the environment in which they live. If the environment they live in is good, then the effect will be good (Zainuddin, 2011).

\section{The dynamics of the adversity quotient of outstanding students with limited conditions}

Based on the results of the case analysis of the three informants (MNS, AFA, RRR), it was known that the "Control" dimension appeared in the informants. In the concept of adversity quotient, the "Control" dimension showed how much the individual could control difficult situations. Highly fighting individuals can control, proactive in approaching adverse situations, and do not feel discouraged when experiencing difficult situations (Chin \& Hung, 2013; Stoltz, 2007). The three informants controlled the limitations of their family's economic conditions by having a frugal lifestyle and an independent attitude. The coping behavior seen in AFA in reducing resentment and disappointment with their family problems showed a very good control. Coping strategies refer to ways of dealing with stress and adversity in some circumstances. This also includes efforts to solve problems and face problematic situations (Lee et al., 2012).

MNS could ignore embarrassment with a good attitude of self-acceptance, while RRR who had low family backgrounds could accept the situation and controlled these difficulties by increasing their potential. The need for education can be alleviated by the existence of scholarships for achievements both academically and non-academically. Accepting yourself according to Kim dan Gal (2014) means being aware, understanding and accepting what it is with the desire and ability to always develop oneself so that you can live your life well and responsibly.

In the difficult situation experienced, the three informants were able to control the downturn so that it did not expand and affected another dimension of life, namely the education dimension. Informants looked for other opportunities to increase self-esteem by achieving and maintaining their achievements. This is in accordance with the concept of adversity quotient by Stoltz (2007) stating that there is an aspect of "Reach", namely the extent to which the difficulties faced will affect the other dimension or side of an individual's life.

In the concept of adversity quotient, there is an "Endurance" dimension, which is to question how long a difficult situation will last (Shen, 2014; Stoltz, 2007). Individuals who have a low response to this dimension will see adversity as an ongoing event. Meanwhile, individuals who have high adversity quotient will still have hope and optimism (Markman et al., 2002). AFA got up and tried to address the life problems with a positive and productive response.

The American Psychological Association uses the term "resilience" to describe a process of adaptation or an individual's ability to recover from adversity, trauma, tragedy, and threats. This means that it is the "resilience" of difficult experiences (Lee et al., 2012; Masten, 2009). Stoltz argues that the adversity quotient is a measure of individual resilience and ability to survive in the face of constant change, various pressures, and difficulties (Canivel, 2010). Being aware of the importance of the future and making parents happy were a special spirit for MNS and AFA to not drag on lamenting their downturn for too long.

The aspect of motivation cannot be separated from the adversity quotient of the informants to keep achieving. Apart from coming from a strong self, external motivation also has a big influence. The figure of a mother was the biggest motivator in facing life's difficulties as well as an 
aspiration for high education for informants to strive for achievement. Research conducted by Xu et al. (2010) states that parental involvement has a relationship with learning based on self-regulation and increase achievement in children.

The strongest motive behind the informants' achievement was the figure of the mother. There was "relational efficacy" in the three informants, namely the ability and belief of a person to manage relationships (emotional closeness) with the people closest to them as well as social support from family relationships to achieve a common expected outcome and the ability to deal with problems and the impact of these problems (Kim \& Park, 2006). The results of his research also suggest that social support from parents has a strong influence on student academic performance.

The competitiveness of the informants in maintaining achievement despite having problems in the scope of their family was strengthened by gratitude and acceptance of the conditions seen in the three informants. In the concept of adversity quotient, there are dimensions of origin and ownership related to guilt and responsibility. Highly fighting individuals are willing to accept the circumstances and consequences of difficult situations, take responsibility and will not blame others (Akbar et al., 2014; Santos, 2012; Shen, 2014; Stoltz, 2007).

Gratitude and good self-acceptance in the informants were obtained from the mother figure who always had taught life lessons since childhood. Mother gave advice and stories about how to struggle to survive, to always be grateful and accept the situation, so that informants were more mature and skilled in dealing with difficult situations. This is in line with the opinion of Zainuddin (2011) saying that the way parents educate will greatly affect the adversity quotient of children. Good parenting where parents provide guidance and teach skills in facing life's difficulties as a provision for children to face their future will result in effective behavior.

The uniqueness of this study with several previous studies is the emergence of aspects of Relational Efficacy between mothers and informants in achievement. Fatherless was also found on the problems of each informant which was also one of the inhibiting factors and the gratitude internalized by the informants on the dynamics of adversity quotient in maintaining achievement despite having limited conditions.

After conducting the research, analysis and discussion, the researchers can provide limitations in this study, namely, lack of data from supporting informants at one of the informants at the tertiary education level. This causes the data obtained to be less exploratory and not actual in accordance with the level of education being taken. For future researchers, it is hoped that they can dig up data by involving more supporting informants so that the information obtained is richer and more complete. The world of education, both in the family, school and community circles, can play an active role in shaping the quality of the next generation by equipping them with fighting intelligence from an early age, in order to have a strong mentality in facing various life problems in the future.

\section{CONCLUSION}

The inhibiting factor for the adversity quotient of outstanding students with limited conditions was the unstable emotional regulation in facing difficulties which results in decreased achievement. Family finances that were inadequate to meet the informants' educational needs, the crisis of family functioning, and the fatherless problems of the three research informants were also factors inhibiting their adversity quotient.

While the supporting factors for the adversity quotient of outstanding students with limited conditions were 1) Internal factors, among others; Informants had competitiveness (competitor 
spirit), coping behavior and ability to rise up to make improvements (resilience), had a strong internal purpose and motivation to remain productive in achieving higher education and accomplishing achievement. Self-awareness and ability to think positively with gratitude. 2) Social support from the environment a) Family environment, namely factors of family functioning, material and emotional support from parents, appreciation (reward) for achievement. b) School environment leads to moral and emotional support given from friends and teachers, such as attention, motivation, giving direction and helping to alleviate difficulties. c) Community environment, such as scholarship assistance, awards or coaching money from institutions or groups of community organizations. Learning support facilities were also given from neighbors or relatives.

The dynamics of the adversity quotient of outstanding students with limited conditions were: Informants controlled economic hardship by living frugally, being concerned, and accepted the situation by helping to ease the economic burden of parents. They also had good self-regulation in controlling difficult situations so as not to spread and affect other dimensions of life, namely the dimension of education. Compensation was done by continuing to learn and improve achievement. Resilience behavior or the ability to get up and improve the situation was more visible in informants of broken home victims and survivors of domestic violence. Self-awareness of the importance of the future was a special spirit for the three informants to gain achievements. The existence of gratitude, made the informants more excited to rise from adversity to achieve a better life, accompanied by strong motivation and relational efficacy between the mother and the informants to achieve the expected results together.

\section{REFERENCES}

Acharya, N., \& Joshi, S. (2011). Achievement motivation and parental support to adolescents. Journal of the Indian Academy of Applied Psychology, 37(1), 132-139. Retrieved from https:// bit.ly/3ncihon

Akbar, Y. R., Supriyono, Y., \& Ramli, A. H. (2014). Peran emotional quotient dan adversity quotient terhadap kecemasan menghadapi dunia kerja pada siswa SMK. Jurnal, 1-17. Retrieved from https:/www.dropbox.com/s/auypllxq7xla4gd/jppiodd090008.pdf?dl=0

Annisa, L., \& Swastiningsih, N. (2015). Dukungan sosial dan dampak yang dirasakan oleh ibu menyusui dari suami. Emphaty: Jurnal Fakultas Psikologi, 3(1), 16-22. Retrieved from http://journal.uad.ac.id/index.php/EMPATHY/article/view/3013

Azwar, S. (2007). Tes prestasi dan pengukuran prestasi belajar. Yogyakarta: Pustaka Pelajar.

Bennu, S. (2012). Adversity Quotient: Kajian kemungkinan pengintegrasiannya dalam pembelajaran matematika. Jurnal AKSIOMA, 1(1), 55-62. Retrieved from http://jurnal.untad.ac.id/ jurnal/index.php/aksioma/article/view/1279

Canivel, L. D. (2010). Principals' Adversity Quotient: Styles, performance and practice [Master thesis, University of the Philippines, Diliman, Quezon City]. Retrieved from https://www. peaklearning.com/wp-content/uploads/2019/05/PEAK_GRI_canivel.pdf

Chin, P.-L., \& Hung, M.-L. (2013). Psychological contract breach and turnover intention: The moderating roles of adversity quotient and gender. Social Behavior and Personality: An 
International Journal, 41(5), 843-859. https://doi.org/10.2224/sbp.2013.41.5.843

Creswell, J. W. (2010). Research design pendekatan kualitatif, kuantatif, dan mixed. Yogyakarta: Pustaka Pelajar.

Departemen Pendidikan Nasional. (2007). Kamus besar bahasa Indonesia (ed.3). Jakarta: Balai Pustaka.

Dewi, N. A. K., Zukhri, A., \& Dunia, I. K. (2014). Analisis faktor-faktor penyebab anak putus sekolah usia pendidikan dasar di Kecamatan Gerokgak tahun 2012/2013. Jurnal Pendidikan Ekonomi UNDIKSHA, 4(1), 1-12. Retrieved from https://ejournal.undiksha.ac.id/index. $\mathrm{php/JJPE/article/view/1898/1650}$

Hadi, S. (2016). Pemeriksaan keabsahan data penelitian kualitatif pada skripsi. Jurnal Ilmu Pendidikan, 22(1), 74-79. Retrieved from http://journal.um.ac.id/index.php/jip/article/ view/8721/4194

Herawaty, Y., \& Wulan, R. (2013). Hubungan antara keberfungsian keluarga dan daya juang dengan belajar berdasar regulasi diri pada remaja. Jurnal Psikologi, 9(2), 138-147. Retrieved from http://ejournal.uin-suska.ac.id/index.php/psikologi/article/view/176

Hidayat, A. F. (2013). Hubungan regulasi diri dengan prestasi belajar kalkulus II ditinjau dari aspek metakognisi, motivasi dan perilaku. Jurnal Elektronik Pendidikan Matematika Tadulako, 1(1), 1-8. Retrieved from http://portalgaruda.fti.unissula.ac.id/index.php? ref=browse \&mod=viewarticle \&article $=111564$

Huijuan, Z. (2009). The adversity quotient and academic performance among college sudents at ST. Joseph's College Quezon City [Ungraduate thesis, St. Joseph's College, Quezon City]. Retrieved from https://www.peaklearning.com/wp-content/uploads/2019/05/PEAK_GRI _huijuan.pdf

Kim, S., \& Gal, D. (2014). From compensatory consumption to adaptive consumption: The role of self-acceptance in resolving self-deficits. Journal of Consumer Research, 41(2), 526-542. https://doi.org/10.1086/676681

Kim, U., \& Park, Y. (2006). Indigenous psychological analysis of academic achievement in Korea: The influence of self-efficacy, parents, and culture. International Journal of Psychology, 41(4), 287-291. https://doi.org/10.1080/00207590544000068

Lee, T. Y., Cheung, C. K., \& Kwong, W. M. (2012). Resilience as a positive youth development construct: A conceptual review. The Scientific World Journal, 1-9. https://doi. org/10.1100/2012/390450

Lerner, H. (2011, November 27). Losing a father too early. Psychology Today. Retrieved from https:// www.psychologytoday.com/us/blog/the-dance-connection/201111/losing-father-too-early

Lubow, G. P. ., Beevers, C. G., Bishop, D. S., \& Miller, I. W. (2009). Family functioning is associated with depressive symptoms in caregivers of acute stroke survivors. Archives of Physical Medicine and Rehabilitation, 90(6), 947-955. https://doi.org/10.1016/j.apmr.2008.12.014

Manurung, R. (2008, March 22). 12 juta anak indonesia putus sekolah. Ayomerdeka. Retrieved from 
https://ayomerdeka.wordpress.com/2008/03/22/12-juta-anak-indonesia-putus-sekolah/

Markman, G., Baron, R. A., \& Balkin, D. (2002). Adversity quotient: Perceived perseverance and new venture formation. Entrepreneurship Research, 1-15. Retrieved from https://www. peaklearning.com/wpcontent/uploads/2019/05/peak_gri_markman.pdf

Maslihah, S. (2011). Studi tentang hubungan dukungan sosial, penyesuaian sosial dilingkungan sekolah dan prestasi akademik siswa SMPIT Assyfa Boarding School Subang Jawa Barat. Jurnal Psikologi, 10(2), 103-114. Retrieved from https://ejournal.undip.ac.id/index.php/ psikologi/article/view/2848

Masten, A. S. (2009). Ordinary magic: Lessons from research on resilience in human development. Education Canada, 49(3), 28-32. https://doi.org/10.14710/jpu.10.2.103-114

Novianty, M. E. (2014). Penerimaan diri dan daya juang pada wanita penderita Systhemic Lupus Erythematosus (SLE). Psikoborneo: Jurnal Ilmiah Psikologi, 2(1), 28-33. Retrieved from http://e-journals.unmul.ac.id/index.php/psikoneo/article/view/3570

Direktorat Jendral Pendidikan Tinggi. (2010). Pedoman umum pemilihan mahasiswa berprestasi. Retrieved from http://lldikti3.kemdikbud.go.id/html/wp-content/uploads/2010/05/ pedoman-mawapres.pdf

Menteri Sosial Republik Indonesia. (2011). Peraturan Menteri Sosial tentang Perubahan atas Peraturan Menteri Sosial Nomor 108/HUK/2009 tentang Sertifikasi Bagi Pekerja Sosial Profesional dan Tenaga Kesejahteraan Sosial. Retrieved from https://peraturan.bpk.go.id/ Home/Details/130572/permensos-no-8huk2011-tahun-2011

Phoolka, S., \& Kaur, N. (2012). Adversity quotient: A new paradigm to explore. The International Jurnal's: Research Journal of Social Science \& Management, 2(7), 109-117. Retrieved from https://www.theinternationaljournal.org/ojs/index. php?journal=tij\&page=article\&op=view\&path\%5B\%5D=1397\&path\%5B\%5D=pdf

Ramadhanu, M., \& Suryaningrum, C. (2014). Adversity quotient ditinjau dari orientasi locus of control pada individu difabel. Jurnal Ilmiah Psikologi Terapan, 2, 152-167. Retrieved from http://ejournal.umm.ac.id/index.php/jipt/article/view/1777/1865

Santos, M. C. J. (2012). Assesing the effectiveness of the adapted adversity quotient program in a special education school. Journal of Arts, Science \& Commerce, III, 4 (2), 13-23. Retrieved from https://www.researchgate.net/profile/Maria_Cristina_Santos2/publication/265846946_ assesing_the_effectiveness_of_the_adapted_adversity_quotient_program_in_a_special_ education_school/links/541db9fc0cf241a65a189933/assesing-the-effectiveness-of-theadapted

Scott, M., Foley, K.-R., Bourke, J., Leonard, H., \& Girdler, S. (2014). "I have a good life": The meaning of well-being from the perspective of young adults with down syndrome. Disability and Rehabilitation, 36(15), 1290-1298. https://doi.org/10.3109/09638288.2013.854843

Shen, C.Y. (2014). The relative study of gender roles, and job stress and adversity quotient. The Journal of Global Business Management, 10(1), 19-32. Retrieved from http://www.jgbm. org/page/3 Shen Chao-Ying.pdf 
Stoltz, P. G. (2007). Adversity quotient @ work. Batam: Interaksara.

Sunandar, M. A., Zaenuri, \& Dwidayati, N. K. (2018). Mathematical problem solving ability of vocational school students on problem based learning model nuanced ethnomatematics reviewed from adversity quotient. Unnes Journal of Mathematics Education Research, 7(1), 1-8. Retrieved from https://journal.unnes.ac.id/sju/index.php/ujmer/article/ view/21277/10428

Sunarty, K. (2016). Hubungan pola asuh orangtua dan kemandirian anak. Journal of EST, 2(3), 152-160. Retrieved from https://media.neliti.com/media/publications/177109-IDhubungan-pola-asuh-orangtua-dan-kemandir.pdf

Republik Indonesia. (2009). Undang-Undang Republik Indonesia Nomor 11 Tahun 2009 tentang kesejahteraan sosial. Retrieved from https://pkh.kemsos.go.id/dokumen/ DOCS20181009100453.pdf

Wardani, W. S. K., \& Saidiyah, S. (2016). Daya juang mahasiswa asing. Psympathic : Jurnal Ilmiah Psikologi, 3(2), 213-224. https://doi.org/10.15575/psy.v3i2.1111

Xu, M., Kushner Benson, S. N., Mudrey-Camino, R., \& Steiner, R. P. (2010). The relationship between parental involvement, self-regulated learning, and reading achievement of fifth graders: A path analysis using the ECLS-K database. Social Psychology of Education, 13(2), 237-269. https://doi.org/10.1007/s11218-009-9104-4

Zainuddin. (2011). Pentingnya adversity quotient dalam meraih prestasi belajar. Jurnal Guru Membangun, 26(2), 1-10. Retrieved from https:/jurnal.untan.ac.id/index.php/jgmm/ article/view/308/314 